\title{
Meeting Or Beating Analysts' Revenue Forecasts Using Advertising Activities
}

\author{
Dong Hyun Son, Hankuk University of Foreign Studies, South Korea
}

\begin{abstract}
This paper investigates the relationship between the likelihood of accomplishing the revenue expectations and the use of firms' advertising expenditures depending on firms' growth properties. First, using the analysts' revenue forecasts as a proxy of revenues expected by market participants, the test shows that growth firms spend more resources in their advertising activities to boost up their reported revenues than non-growth firms do. The paper also examines whether the effect of the interaction between the growth properties of firms and the use of advertising expenses on the probability of achieving analysts' revenue forecasts can vary conditionally on firms' business strategies. Empirical results display that the positive relation between growth firms and the probability of meeting or exceeding analysts' revenue forecasts are statistically significant for cost leadership firms but not for differentiation firms. These findings suggest that unlike differentiators, cost leaders with growth properties are more likely to achieve favorable revenue surprises through advertising activities.
\end{abstract}

Keywords: Financial Analysts; Analysts’ Revenue Forecasts; Advertising Expenditures; Growth; Differentiation; Cost Leadership

JEL Classification: M41, G14

\section{INTRODUCTION}

1 $\mathrm{n}$ this study, I test whether the interaction between a firm's growth properties and advertising expenditure growth is associated with the probability of meeting or exceeding the market expectations for revenues ${ }^{1}$. Growth firms may manage their advertising activities upward to provide desirable revenue signals to the market compared with non-growth firms to the extent that investors give more weight on the revenue information of growth firms than those of non-growth firms. Further, the effectiveness of advertising expenses within a short period of time can be different depending on firm's business strategy. Therefore, I also investigate whether the effect of a link between advertising expenditures and growth properties on meeting or beating analysts' revenue forecasts varies conditional on two business strategies: 1) cost leadership and 2) differentiation.

Some studies provide evidence that growth firms are more likely to meet or beat analysts' revenue forecasts than nongrowth firms because revenue signals are considered more important news for growth firms than for non-growth firms (Ertimur, Livnat \& Martikainen, 2003; Son, 2016). Prior research demonstrates that growth firms take additional actions, such as accrual revenue management, to avoid negative revenue surprise (Stubben, 2006; Son, 2016) ${ }^{2}$. In this study, I particularly focus on advertising activity management as a tool for growth firms to generate desirable revenue signals because prior studies suggest that companies can increase their current period sales by spending much money on advertising (Lodish et al. 1995; Joshi \& Hanssens 2010) ${ }^{3}$. Although Cohen, Mahruwala \& Zach (2010) present that firms generally manage advertising expenses downward to meet or beat earnings benchmarks, the downward manipulation of advertising expenditures to generate favorable earnings news may not be completely applied to growth firms whose revenue signals are more important than earnings. Thus, I test the effect of an interaction between growth

\footnotetext{
${ }^{1}$ The latest consensus of the analysts' annual revenue forecasts is used as a proxy for revenues expected by market participants. The consensus is defined as a median of analysts' forecasts issued a month before earnings announcement.

${ }^{2}$ Consistent with previous literature, revenue surprises are computed by actually announced revenues minus the latest consensus of the analysts' revenue forecasts.

${ }^{3}$ In this study, sales and revenues are used interchangeably.
} 
property and advertising expenditure growth on the probability of generating zero or positive sales revenue surprises. The results show that growth firms have higher tendency to achieve analysts' revenue forecasts by increasing their advertising activities than non-growth firms.

McAlister, Srinivasan, Jindal \& Cannella (2016) also present that the advertising effectiveness on sales and firm value can differ depending on firms' business strategies, that is, cost leadership versus differentiation. They argue that differentiators use advertising to build their brand equity, whereas cost leaders utilize it to increase current period sales. Therefore, I expect that advertising may exert more immediate effect on short-term revenues for cost leaders than for differentiators. Advertising expenses would be mainly used by cost leaders to boost current period revenues, but they would be mostly used by differentiators to build their brand equities, which require them to invest long periods of time. Using the volatility of research and development (R\&D) expenditures as a proxy for firms' business strategy, I test the effect of an interaction variable between advertising expenditure growth and firm's growth properties on the possibility of achieving sales expectations conditional on a firm's business strategy. The empirical analysis shows that the interaction term between growth proxy and advertising expenses is significantly and positively associated with the probability of meeting or beating analysts' revenue forecasts for cost leadership firms. By contrast, this positive relationship becomes statistically insignificant for differentiation firms. These results suggest that growth firms sustaining cost leadership strategy increase their advertising to produce zero or positive sales surprises, whereas growth firms using differentiation strategy do not manage their advertising activity upward to avoid negative revenue surprises.

This study can contribute to the accounting and finance literature in several ways. First, previous research document that firms use discretionary revenues to achieve zero or positive revenue shocks (Stubben, 2006). By exploring advertising activity management, the paper analyzes an additional tool available to managers for avoiding negative revenue surprises. Second, although prior studies focus on the reduction of advertising expenses to meet or beat the expected earnings (Cohen et al. 2010; Chapman \& Steenburgh, 2011), this study suggests that advertising activity management can be utilized differently under certain circumstances by showing the increased advertising expenditure of growth firms to avoid undesirable revenue surprises. Third, by showing that advertising is more effective for growth firms with cost leadership strategy to generate short-term favorable revenue news relative to growth firms with differentiation strategy, this study can provide additional evidence that the effectiveness of advertising can vary with firm business strategy.

The remainder of this paper is organized as follows. Section 2 discusses the related literature and hypothesis development. The next section describes the data selection. Then, section 4 describes the testable research designs. Section 5 provides detail descriptive statistics as well as the results from the empirical tests. Finally, section 6 contains the conclusion.

\section{RELATED LITERATURE AND HYPOTHESIS}

Earlier literature documents that there are irregularly high proportion of firms meeting or beating the market expectation for earnings (Brown, 2001; Matsumoto, 2002). As an explanation for this phenomenon, researchers provide evidence that firms which meet or beat benchmarks for earnings enjoy higher market equity premium while firms which miss the benchmarks receives severe penalties in their equity values (Bartov, Givoly \& Hayn, 2002; Kasznik and McNichols, 2002). After documenting strong incentives for firms' managers to achieve earnings benchmarks, numerous papers show that firms tend to manage their reported earnings to avoid negative earnings surprises. Using discretionary accruals, Payne and Robb (2001) present that firms manipulate earnings upward to meet or exceed earnings benchmark when their pre-managed earnings are below a consensus of analysts' earnings forecasts. Moreover, as an evidence of earnings management Dechow, Richardson \& Tuna (2000) and Burgstahler and Eames (2006) report that firms successfully achieving zero or positive earnings surprises report higher discretionary accruals relative to firms having negative earnings surprises.

In addition to earnings benchmark, several studies focus on an another benchmark, revenue, and provide evidence that the market rewards (penalizes) to firms generating zero or positive (negative) surprises in earnings as well as revenue by providing higher equity premiums (penalties) (Jegadeesh \& Livnat, 2006; Carvajal, Coulton \& Jackson, 2015; Chandra \& Ro, 2008). Further interesting findings are reported by Ertimur et al. (2003). They provide evidence that 
the market participants respond significantly negatively if growth firms miss their revenue expectations regardless of their earnings signals. However, non-growth firms are not penalized by the market even if they miss revenue expectations as long as they make favorable earnings surprises. Their findings suggest that managers for growth firms may carefully pay attention on their revenue signs, because the costs associated with failing to meet revenue expectations for growth firms are much more severe than those for non-growth firms. Consistent with prior findings, Son (2016) find that non-growth firms are less likely to meet or meet analysts' revenue forecasts than growth firms. In addition, some studies investigate whether companies take extra actions to meet or exceed the expected revenue targets. Stubben (2006) and Son (2016) report that growth firms are more actively involved in accrual revenue management to avoid intensive market reactions to negative revenue signals than non-growth firms.

In this study, I specifically consider advertising activities as another tool possibly used by firms to achieve the revenues expectations because previous marketing research suggests that advertising is positively associated with current period revenues (Bagwell, 2007; Hanssens, 2009; Lodish et al. 1995; McAlister et al. 2016). Firms may increase their advertising expenditures when they possess strong incentives to meet or exceed revenue targets. Nevertheless, Cohen et al. (2010) suggest that altering advertising expenses may have different implications on short-term earnings. They examine whether firms manage their advertising expenses upward or downward to generate favorable earnings news. They provide evidence that firms, on average, reduce advertising spending to avoid negative earnings news, such as losses and earnings decreases. However, they do not consider other possibilities that advertising may be used in different ways for different purposes. In the present research, I argue that the downward manipulation of advertising expenditures to generate favorable earnings news may not be completely applied to growth firms whose revenue signals are more important than earnings. Contrary to Cohen et al. (2010), this study focuses on the use of advertising activities to produce desirable revenue signals, not earnings signals, depending on a firms' growth properties. Growth firms, which first require achieving the expected revenue targets relative to non-growth firms, are more likely to increase advertising expense, although this phenomenon may require them to sacrifice their earnings due to the increase of expenses. Therefore, I posit that growth firms may increase advertising activities to boost their reported revenues to meet or beat analysts' revenue forecasts, even though the consequence of these increased expenditures may damage their reported earnings. Therefore, the first hypothesis is as follows:

H1: The interaction between growth firms and advertising expenditures is positively related with the probability of meeting or exceeding analysts' revenue forecasts.

McAlister et al. (2016) suggest that the advertising effectiveness on sales and firm value can be different depending on firms' business strategies, that is, cost leadership versus differentiation. Their first finding indicates that advertising is positively related to current period sales for cost leaders and differentiators. They also find that the relationship between advertising and firm value are stronger for firms using the differentiation strategy than for firms using cost leadership strategy, because the differentiators assert their point of difference that advertising can elaborate into brand equity, suggesting that they may be required to maintain consistent spending on advertising over certain periods of time. These results imply that differentiators more actively use advertising to build their brand equity, whereas cost leaders more extensively utilize it to increase current period sales. That is, advertising may exert more instant effects on short-term revenues for cost leaders than for differentiators. Consequently, I infer that growth firms pursuing cost leadership strategy may more aggressively use advertising activities, such as promotions, to produce favorable shortterm responses in revenues, while growth firms following differentiation strategy may less aggressively use advertising activities to generate a favorable revenue signals. Thus, the second hypothesis is as follows:

H2: The interaction between growth firms and advertising expenditures is more positively related with the probability of meeting or exceeding analysts' revenue forecasts for firms with cost leadership strategy than for those with differentiation strategy.

\section{SAMPLE SELECTIONS}

Similar to prior research (Rees \& Sivaramakrishnan, 2007; Bartov et al. 2002), analysts' revenue forecasts are collected from the Institutional Brokers Estimate System (I/B/E/S) database. I define the consensus of analysts' forecasts as the latest medians of analysts' annual revenue forecasts before earnings announcement. For compatibility, actual revenues announced by firms are also collected from the I/B/E/S. I limit the sample period between 1997 and 
2015 because a machine-readable analysts' revenue forecasts are provided by the I/B/E/S since $1996^{4}$. Following prior studies (Bartov et al. 2002), I require at least three revenue forecasts to use meaningful median estimates. Observations with no prior period revenue forecast errors are excluded. Advertising expenditures and R\&D expenditure data are compiled from the COMPUSTAT database. This research focuses on an annual basis because COMPUSTAT no longer provides quarterly advertising expense data. Observations with advertising expenditures below $\$ 100,000$ (Cohen et al. 2010) or those without advertising expenditure data are eliminated from the final dataset. Revenue forecasts for firms with negative stock price and negative market value of equity are also removed. All other relevant accounting data are collected from the COMPUSTAT annual database. Therefore, the final sample is constructed by total 9,080 firm-year observations.

\section{RESEARCH DESIGN}

\subsection{Research Model for H1}

In examining whether the association between the likelihood of meeting or exceeding analysts' revenue expectations and the use of advertising expenditures depending on firms' growth properties, the logistic regression analysis is performed by using the empirical model as follows:

$\operatorname{Prob}(M B R=1 \mid X)=F\left(\alpha_{0}+\alpha_{1} M_{-} t_{-} B_{j, t}+\alpha_{2}\right.$ Advertising $_{j, t}+\alpha_{3} M_{t o_{B}}{ }_{j, t} \times$ Advertising $_{j, t}$

$+\alpha_{4}$ LTG $_{R I S K}{ }_{j, t}+\alpha_{5}$ LOSS $_{j, t}+\alpha_{6}$ Size $_{j, t}+\alpha_{7}$ VOL $_{\text {Earnings }_{j . t}}+\alpha_{8}$ Indpro $_{\text {value }_{i, t}}+\alpha_{9}$ POSREVC $_{j, t}$

$+\alpha_{10}|F E|_{i, t}+\alpha_{11} e_{-} \operatorname{Sur}_{j, t}+\varepsilon_{j, t}$

where

$f\left(\alpha^{\prime} X\right)=\frac{e^{\alpha^{\prime} X}}{1+e^{\alpha^{\prime} X}}$

I classify firms with reported revenues greater than or equal to analysts' revenue forecasts as firms meeting or beating analysts' revenue forecasts. Consistent to previous research, I also include the market-to-book ratio as the proxy of growth properties in the model. In addition, I focus on advertising expenditure growth rather than annual advertising expenses because a main interest is on the increase of advertising activities for growth firms to meet or beat analysts' revenue forecasts. The advertising growth is measured as yearly changes in advertising expenses for each firm divided by the firm's prior year advertising expenditures. The market-to-book ratio (M_to_Bj,t) and advertising growth (Advertisingj,t,) variables are included in the above model in discrete forms. High growth firms are defined as firms included in the top $30 \%$ of market-to-book ratio, and the rest of other firms are classified as low growth firms. Similarly, firms classified in the top 30\% of advertising expenditure growth are considered firms with high advertising expenditure, and the rest of the firms are identified as firms with low advertising expenditure. A variable of interest is an interaction term between advertising expenditures and growth proxy ( $M_{-}$to_B $\mathrm{j}, \mathrm{t} \times$ Advertisingj, $\mathrm{t}$ ). A coefficient on the interaction term indicates the effect of the relationship between growth firms and the use of advertising on the probability of zero or positive revenue surprises. To support H1, the coefficient $\alpha 3$ on the interaction term is expected to be statistically and significantly positive, which implies that growth firms are more likely to achieve revenue expectations by increasing advertising activities.

To control potential confounding factors suggested in previous literature, several variables are included in the model. To control the firm's litigation risk (Matsumoto, 2002), LTG_RISKj,t is included. The model also contains positive revenue changes (POSREVC) and the average of annual industrial production growth(INDPROD) to deal with the unexpected macroeconomic shocks (Athanasakou, Strong \& Walker 2009). Loss situations (Lossj,t) and earnings volatility (VOL_Earningsj,t) are also included, given that earlier research indicates that revenues are more value relevant when the earnings information of the firms is insignificant (Callen, Robb \& Segal 2008; Zhang, 2006). To handle the effect of firm size, a variable, Sizej,t is included. Further, following Matsumoto (2002), revenue forecast

${ }^{4}$ Because of the limited sample observations, analysts' revenue forecasts in 1996 is excluded. 
errors $(|\mathrm{FE}|)$ are included to control the uncertain forecasting environment. Finally, current period earnings surprises are comprised in the model. The detailed descriptions of all these variables are provided in Appendix A.

\subsection{Research Model for $\mathrm{H} 2$}

To examine the next hypothesis, the volatility of the annual R\&D expenditures is used as a proxy to classify each firm's business strategy into two groups: differentiators and cost leaders. Miles and Snow (1978) argued that firms pursuing a strategy either differentiation or cost leadership are required a certain persistence to make their strategies successful. Hambrick (1985) also emphasized the important of persistency in R\&D activities to become efficient strategy. Furthermore, Miller (1987) claimed that firms pursuing differentiation strategy are inclined to make large R\&D investments not only to enhance their innovative ability but also to sustain their competitive advantages in the market. Accordingly, to be successful differentiator, firms pursuing differentiation strategy are more likely to maintain a certain level of investments in R\&D activities. On the other hand, Porter (1985) suggested that cost leadership firms are inclined to control costs tightly, refrain from frequently incurring expenses from innovation. Moreover, Miller (1987) suggested that innovation is not often needed to firms pursuing cost leadership because they confront generally low unpredictable market environment. Hence, the R\&D investment tendency of firms pursuing cost leadership strategy are expected to be irregular patterns since they are likely to make R\&D investments such as a development of an efficient production system only if they have extra spending capacity. Therefore, the volatility of R\&D expenditures is expected to be varied depending on firm's strategy either differentiator or cost leadership. The volatility of $R \& D$ expenditures is estimated by the three-year variance of the firm's R\&D expenses deflated by the three-year mean of R\&D expenditures. To investigate the effect of a relationship between advertising expenditures and growth property on probability of meeting or beating analysts' revenue forecasts conditional on firm's business strategy, I define firms included in the top $30 \%$ of R\&D expenditure volatility as cost leaders and other firms are classified as differentiators. After dividing the sample into two groups, I perform the logistic analysis for each group using Model (1) to test the second hypothesis. Similar to the first analysis, a variable of interest is an interaction between advertising expenditures and growth proxy (M_to_Bj, $\mathrm{t} \times$ Advertisingj,t) for each group. A comparison of the interaction term between the two groups can examine whether the effect of the relationship between advertising and growth property on the probability of meeting or beating the expected revenue may vary depending on the firm's business strategy. To be consistent with the $\mathrm{H} 2$, a coefficient $\alpha 3$ on the interaction term are expected to be significantly positive for cost leaders but not for differentiators.

\section{EMPIRICAL RESULTS}

\subsection{Descriptive Statistics}

The descriptive statistics are presented in Panel A of Table 1. The average of MBR variable suggests that roughly $58 \%$ of the final sample are identified as the firms achieving zero or positive revenue surprises. Also, the means of two categorical variables, market-to-book ratio and advertising, are 0.314 and 0.298 , respectively. Approximately $43 \%$ of firms in the sample are in high litigation risk industries. The mean (median) of firm size is 7.58 (6.38). On average, $20 \%$ of sample firms report losses between 1997 and 2015. The earnings volatility and revenue forecasts errors have the mean of 1.44 and 0.86 , while the medians are 0.197 and 0.011 , suggesting that both variables are slightly right skewed. Furthermore, the average of POSREVC indicates that nearly $77 \%$ of firms in the sample increase their revenues compared to the previous year.

In Panel $\mathrm{B}$, the results from t-test for MBR=1 and 0 indicates that the market-to-book ratios of firms successfully achieving analyst's revenue expectations have higher than those of firms missing the expected revenue, which is consistent with prior literature (Son, 2016). In addition, compared with the firms failing to meet the targeted revenue, firms achieving it have higher advertising expenditures, which suggest that firms use advertising activities to provide favorable revenue signals. 
Table 1. Descriptive Statistics

\begin{tabular}{l|c|c|c|c|c|c}
\hline \multicolumn{2}{l}{ Panel A: Descriptive Statistics for All Variables } & & & & \\
\multicolumn{1}{r|}{ Variable } & $\mathbf{N}$ & Mean & Std Dev & Median & $\mathbf{1 Q}$ & $\mathbf{3 Q}$ \\
\hline MBR & 9080 & 0.576 & 0.494 & 0.000 & 1.000 & 1.000 \\
\hline M_to_B & 9080 & 0.314 & 0.464 & 0.000 & 0.000 & 1.000 \\
\hline Advertising & 9080 & 0.298 & 0.458 & 0.000 & 0.000 & 1.000 \\
\hline LTG_RISK & 9080 & 0.425 & 0.494 & 0.000 & 0.000 & 1.000 \\
\hline Loss & 9080 & 0.200 & 0.400 & 0.000 & 0.000 & 0.000 \\
\hline Size & 9080 & 7.583 & 1.685 & 6.380 & 7.387 & 8.590 \\
\hline VOL_Earnings & 9076 & 1.440 & 3.593 & 0.197 & 0.429 & 1.136 \\
\hline Indpro_value & 9080 & 1.098 & 4.123 & 1.215 & 2.508 & 2.930 \\
\hline POSREVC & 8933 & 0.767 & 0.423 & 1.000 & 1.000 & 1.000 \\
\hline |FE & 9075 & 0.086 & 0.156 & 0.011 & 0.031 & 0.086 \\
\hline E_Sur & 9078 & -0.002 & 0.020 & -0.001 & 0.000 & 0.002 \\
\hline
\end{tabular}

\section{Panel B: Mean Difference between $M B R=1$ and $M B R=0$}

\begin{tabular}{|l|c|c|r|r|r}
\multicolumn{1}{c}{ Variables } & MBR=0 & MBR=1 & Diff(C2-C3) & t Value & Pr $>|\mathbf{t}|$ \\
\hline M_to_B & 0.2604 & 0.3527 & -0.0923 & -9.42 & $<0.0001$ \\
\hline Advertising & 0.2536 & 0.3315 & -0.0778 & -8.04 & $<0.0001$ \\
\hline LTG_RISK & 0.4195 & 0.4290 & -0.0095 & -0.91 & 0.3646 \\
\hline Loss & 0.2287 & 0.1785 & 0.0503 & 5.93 & $<0.0001$ \\
\hline Size & 7.4340 & 7.6929 & -0.2589 & -7.25 & $<0.0001$ \\
\hline VOL_Earnings & 1.3568 & 1.5010 & -0.1442 & -1.89 & 0.0588 \\
\hline Indpro_value & 0.9201 & 1.2293 & -0.3092 & -3.53 & 0.0004 \\
\hline POSREVC & 0.6948 & 0.8206 & -0.1258 & -14.05 & $<0.0001$ \\
\hline FE & 0.0926 & 0.0803 & 0.0123 & 3.73 & 0.0002 \\
\hline E Sur & -0.0050 & 0.000254 & -0.00525 & -12.66 & $<0.0001$
\end{tabular}

* MBR is an indicating variable which is equal to 1 if a firm's revenue surprise is equal to or greater than zero. Revenue surprises are calculated by firms' reported revenues minus the latest median of revenue forecasts. See Appendix for detailed variable definitions.

The results gathered from the Pearson (Spearman) correlation analysis among all the variables are also documented in Table 2. Overall level of correlations among all explanatory variables is considered to be low. $(<0.2)$. Therefore, it reasonable to conclude that there is no multicollinearity problem among the independent variables.

Table 2. Pearson (above the diagonal) and Spearman (below the diagonal) Correlation Coefficients Prob $>|r|$ under $\mathrm{H} 0:$ ho $=0$

\begin{tabular}{l|c|c|c|c|c}
\hline \multirow{2}{*}{ M_to_B } & M_to_B & Advertising & LTG_RISK & Loss & Size \\
\hline \multirow{2}{*}{ Advertising } & 1.000 & 0.087 & 0.103 & -0.072 & 0.286 \\
\hline \multirow{2}{*}{ LTG_RISK } & 0.087 & $<0.0001$ & $<0.0001$ & $<0.0001$ & $<0.0001$ \\
\hline \multirow{2}{*}{ Loss } & $<0.0001$ & 1.000 & 0.055 & 0.020 & -0.065 \\
\hline \multirow{2}{*}{ Size } & 0.103 & 0.055 & $<0.0001$ & 0.062 & $<0.0001$ \\
\hline \multirow{2}{*}{ VOL_Earnings } & $<0.0001$ & $<0.0001$ & 1.000 & 0.079 & -0.031 \\
\hline \multirow{2}{*}{ Indpro_value } & -0.072 & 0.020 & 0.079 & $<0.0001$ & -0.002 \\
\hline \multirow{2}{*}{ POSREVC } & $<0.0001$ & 0.062 & $<0.0001$ & 1.000 & $<0.0001$ \\
\hline \multirow{2}{*}{$\mid$ FE } & 0.286 & -0.065 & -0.031 & -0.313 & 1.000 \\
\hline \multirow{2}{*}{ E_Sur } & $<0.0001$ & $<0.0001$ & 0.002 & $<0.0001$ & -0.095 \\
\hline
\end{tabular}




\begin{tabular}{|c|c|c|c|c|c|}
\hline & VOL_Earnings & Indpro_value & POSREVC & $|\mathbf{F E}|$ & E_Sur \\
\hline \multirow{2}{*}{ M_to_B } & -0.063 & 0.075 & 0.145 & -0.157 & 0.054 \\
\hline & $<0.0001$ & $<0.0001$ & $<0.0001$ & $<0.0001$ & $<0.0001$ \\
\hline \multirow{2}{*}{ Advertising } & 0.017 & 0.106 & 0.209 & -0.021 & -0.004 \\
\hline & 0.104 & $<0.0001$ & $<0.0001$ & 0.048 & 0.698 \\
\hline \multirow{2}{*}{ LTG_RISK } & 0.002 & -0.003 & 0.063 & -0.029 & 0.032 \\
\hline & 0.876 & 0.736 & $<0.0001$ & 0.004 & 0.001 \\
\hline \multirow{2}{*}{ Loss } & 0.113 & -0.100 & -0.214 & 0.164 & -0.225 \\
\hline & $<0.0001$ & $<0.0001$ & $<0.0001$ & $<0.0001$ & $<0.0001$ \\
\hline \multirow{2}{*}{ Size } & -0.095 & 0.066 & 0.089 & -0.200 & 0.140 \\
\hline & $<0.0001$ & $<0.0001$ & $<0.0001$ & $<0.0001$ & $<0.0001$ \\
\hline \multirow{2}{*}{ VOL_Earnings } & \multirow{2}{*}{1.000} & -0.009 & -0.047 & 0.083 & -0.028 \\
\hline & & 0.365 & $<0.0001$ & $<0.0001$ & 0.005 \\
\hline \multirow{2}{*}{ Indpro_value } & -0.009 & \multirow{2}{*}{1.000} & 0.220 & -0.093 & 0.013 \\
\hline & 0.365 & & $<0.0001$ & $<0.0001$ & 0.205 \\
\hline \multirow{2}{*}{ POSREVC } & -0.047 & 0.220 & \multirow{2}{*}{1.000} & -0.240 & 0.105 \\
\hline & $<0.0001$ & $<0.0001$ & & $<0.0001$ & $<0.0001$ \\
\hline \multirow{2}{*}{$|\mathbf{F E}|$} & 0.083 & -0.093 & -0.240 & \multirow{2}{*}{1.000} & -0.118 \\
\hline & $<0.0001$ & $<0.0001$ & $<0.0001$ & & $<0.0001$ \\
\hline \multirow{2}{*}{ E_Sur } & -0.028 & 0.013 & 0.105 & -0.118 & \multirow{2}{*}{1.000} \\
\hline & 0.005 & 0.205 & $<0.0001$ & $<0.0001$ & \\
\hline
\end{tabular}

\subsection{Association between the MBR and Advertising depending on Growth Proxy}

Contingency tables in Table 3 illustrates the association between MBR and the use of advertising activities depending on firms' growth properties. These tables are constructed by classifying all firm-year observations based on the indicators of MBR and indicators of high (low) advertising expenditure growth depending on the level of firm's growth proxy, market-to-book ratio. The percentage of firms meeting or exceeding the expected revenue for high-growth firms is $40.29 \%$, whereas the same percentage of low-growth firms is $29.26 \%$. Additionally, the table shows that among the firms increasing advertising expenditures (Advertising=1), the differences between the percentage of firms generating favorable revenue signals $(\mathrm{MBR}=1)$ and the percentage of firms producing unfavorable revenue signals $(\mathrm{MBR}=0)$ are significantly greater for growth firms (12.93) than for non-growth firms (4.58). Overall, these initial findings suggest that growth firms increase their advertising to generate desirable revenue news. Moreover, increasing advertising expenses is more effective way for growth firms to meet or beat the revenue expectations than for nongrowth firms. 
Table 3. Relationship between Advertising Expenditures Growth and the Probability of Meeting or Beating Revenue Expectations depending on Firm's Growth

Contingency Tables

MBR and Advertising Expenditure Growth by the Level of Growth

High Market-to-Book

\begin{tabular}{|c|c|c|c|c|}
\hline \multirow{2}{*}{$\begin{array}{l}\text { Frequency } \\
\text { Percent }\end{array}$} & & \multicolumn{2}{|c|}{ Advertising } & \multirow[b]{2}{*}{ Total } \\
\hline & & 1 & 0 & \\
\hline \multirow{6}{*}{ MBR } & \multirow{2}{*}{1} & 743 & 1101 & 1844 \\
\hline & & $40.29 \%$ & $59.71 \%$ & $64.77 \%$ \\
\hline & \multirow{2}{*}{0} & 274 & 729 & 1003 \\
\hline & & $27.32 \%$ & $72.68 \%$ & $35.23 \%$ \\
\hline & Total & $\begin{array}{l}1017 \\
35.72 \%\end{array}$ & $\begin{array}{l}1830 \\
64.28 \%\end{array}$ & $\begin{array}{l}2847 \\
100\end{array}$ \\
\hline & $x^{2}=$ & & $\mathrm{p}<0.001$ & \\
\hline
\end{tabular}

Low Market-to-Book

\begin{tabular}{|c|c|c|c|}
\hline & \multicolumn{2}{|c|}{ Advertising } & \multirow[b]{2}{*}{ Total } \\
\hline & 1 & 0 & \\
\hline \multirow{2}{*}{1} & 990 & 2394 & 3384 \\
\hline & $29.26 \%$ & $70.47 \%$ & $54.29 \%$ \\
\hline \multirow{2}{*}{0} & 703 & 2146 & 2849 \\
\hline & $24.68 \%$ & $75.32 \%$ & $45.71 \%$ \\
\hline Total & $\begin{array}{l}1693 \\
27.16 \%\end{array}$ & $\begin{array}{l}4540 \\
2.84 \%\end{array}$ & $\begin{array}{l}6233 \\
100\end{array}$ \\
\hline$x^{2}=$ & & $\mathrm{p}<0.001$ & \\
\hline
\end{tabular}

\subsection{Effect of the Interaction between Advertising and Growth Proxy on the Probability of Meeting or Beating Analysts' Revenue Forecasts}

Table 4 displays the results for the effect of the interaction between advertising and growth proxy on the probability of avoiding negative revenue surprises. Colum 4 in Table 4 presents the results without the interaction term while Column 4 shows the results with the interaction term. The results obtained from the analysis without the interaction term show that a coefficient on Advertising $\mathrm{j}_{\mathrm{j}, \mathrm{t}}$ is statistically and significantly positive, which indicate that, generally, firms increasing their advertising expenditures are more successfully to accomplish the market expectations for revenues. That is, firms use advertising activities to increase their reported revenues. Moreover, the results for $\mathrm{H} 1$ are presented in Column 4. A coefficient on the interaction term between advertising and growth proxy ( $M_{-}$to_ $B_{j, t} \times$ Advertising $\mathrm{j}_{\mathrm{j}, \mathrm{t}}$ ) is positive and significant, a factor suggesting that growth firms have higher tendency to meet or to exceed the analysts' revenue expectations by increasing the advertising activities relative to non-growth firms.

Furthermore, Columns 3 and 5 in Table 4 provide the marginal effect of each variable. In the logistic regression, these marginal effects indicate the change of probability with regard to a unit change of the explanatory variable. Hence, the fact that the marginal effect of the interaction term between is 0.0862 means that one unit change of advertising 
expenditures increases the likelihood of achieving zero or positive revenue surprises for growth firms by roughly $9 \%$. This result also confirms that advertising expenses increase the probability for growth firm to avoid negative revenue surprises.

Table 4. Logit Analysis of Using Advertising Expenditures to Achieve Zero or Positive Revenue Surprises conditional on Growth Proxy (Market-to-Book Ratio)

\begin{tabular}{|c|c|c|c|c|}
\hline \multicolumn{5}{|c|}{$\begin{array}{l}\text { Model: Prob }(1 \mid X)=F\left(\alpha_{0}+\alpha_{1} M_{t o_{B}, t}+\alpha_{2} \text { Advertisint }_{j, t}+\alpha_{3} \text { GROWTH }_{j, t} \times A D V_{j, t}+\alpha_{4} \text { LTG }_{R I S K}{ }_{j, t}+\alpha_{5} \text { LOSS }_{j, t}+\alpha_{6} \text { Size }_{j, t}+\right. \\
\alpha_{7} \text { VOL }_{\text {Earnings }_{j, t}}+\alpha_{8} \text { Indpro }_{\text {value }_{j, t}}+\alpha_{9} \text { POSREVC }_{j, t}+\alpha_{10}|F E|_{j, t}+\alpha_{11} E_{S u r}+, t \\
\left.+\varepsilon_{j, t}\right)\end{array}$} \\
\hline VARIABLES & Model (a) & Marginal Effects & Model (b) & Marginal Effects \\
\hline \multirow{2}{*}{ Constant } & $-0.73957^{* * *}$ & & $-0.70464^{* * *}$ & \\
\hline & $(0.129)$ & & $(0.129)$ & \\
\hline \multirow{2}{*}{ M_to_B } & $0.28331^{* * *}$ & $0.0668^{* * *}$ & $0.17216^{* * *}$ & $0.0406^{* * *}$ \\
\hline & $(0.051)$ & & $(0.060)$ & \\
\hline \multirow{2}{*}{ Advertising } & $0.26087^{* * *}$ & $0.0615^{* * *}$ & $0.14306^{* *}$ & $0.0337^{* *}$ \\
\hline & $(0.050)$ & & $(0.060)$ & \\
\hline \multicolumn{5}{|c|}{ Interaction b/w Market-to-Book ratio and Advertising: } \\
\hline \multirow{2}{*}{ MtB_ADV } & & & $0.36577^{* * *}$ & $0.0862^{* * *}$ \\
\hline & & & $(0.105)$ & \\
\hline \multicolumn{5}{|l|}{ Control Variables: } \\
\hline \multirow{2}{*}{ LTG_RISK } & 0.00135 & 0.000318 & -0.00292 & -0.000687 \\
\hline & $(0.045)$ & & $(0.045)$ & \\
\hline \multirow{2}{*}{ Loss } & -0.09431 & -0.0222 & -0.09750 & -0.0230 \\
\hline & $(0.061)$ & & $(0.061)$ & \\
\hline \multirow{2}{*}{ Size } & $0.05710^{* * *}$ & $0.0135^{* * *}$ & $0.05656^{* * *}$ & $0.0133^{* * *}$ \\
\hline & $(0.015)$ & & $(0.015)$ & \\
\hline \multirow{2}{*}{ Vol_Earnings } & $0.02228^{* * *}$ & $0.00525^{* * *}$ & $0.02177^{* * *}$ & $0.00513^{* * *}$ \\
\hline & $(0.006)$ & & $(0.006)$ & \\
\hline \multirow{2}{*}{ Indpro_value } & -0.00170 & -0.000401 & -0.00168 & -0.000397 \\
\hline & $(0.005)$ & & $(0.005)$ & \\
\hline \multirow{2}{*}{ POSREVC } & $0.57532^{* * *}$ & $0.136^{* * *}$ & $0.57963^{* * *}$ & $0.137^{* * *}$ \\
\hline & $(0.056)$ & & $(0.056)$ & \\
\hline \multirow{2}{*}{$|\mathrm{FE}|$} & 0.21503 & 0.0507 & 0.21580 & 0.0508 \\
\hline & $(0.155)$ & & $(0.154)$ & \\
\hline \multirow{2}{*}{ E_Sur } & -0.40160 & -0.0947 & -0.40469 & -0.0953 \\
\hline & $(0.319)$ & & $(0.319)$ & \\
\hline Log Likelihood & -5929.07 & & -5922.94 & \\
\hline Wald Chi-square & 303.10 & & 315.35 & \\
\hline$p$-value & $<0.001$ & & $<0.001$ & \\
\hline Pseudo R-squared & 0.025 & & 0.026 & \\
\hline Total Observations & 8,925 & & 8,925 & \\
\hline
\end{tabular}

\subsection{Effect of the Interaction between Advertising and Growth Proxy on the Probability of Meeting or Beating Analysts' Revenue Forecasts depending on Business Strategy}

Table 5 presents the results of the analysis, which examines whether the effect of a link between advertising expenditures and growth property on the probability of meeting or beating analysts' revenue forecasts varies depending on the firm's business strategies: 1) cost leadership and 2) differentiation. Columns 2 and 4 in the table shows the test results using firms with cost leadership strategy (high volatility of R\&D expenditures) and firms with differentiation strategy (low volatility of $\mathrm{R} \& \mathrm{D}$ expenditures). Consistent with $\mathrm{H} 2$, a coefficient on the interaction term between advertising and the market-to-book ratio is positive and statistically significant for the cost leadership group, but the interaction is not statically significant but is positive. These findings indicate that the growth firms with cost leadership strategy are more likely to achieve zero or positive revenue surprises by increasing their advertising 
expenses. Advertising activities are a more effective tool for avoiding negative revenue surprises for growth firms following cost leadership than for growth firms pursuing differentiation.

The marginal effects of all variables for both groups are also reported in Columns 3 and 5. The marginal effect of M_to_Bj,t $\times$ Advertisingj,t for cost leaders is 0.194 , which suggest that the upward advertising activities contribute to nearly $19 \%$ increase in the probability of meeting or beating the analysts' revenue forecasts when firms are classified into growth firms and cost leadership group. Hence, overall results are consistent with H2.

Table 5. Logit Analysis of the Effects of the Association between Advertising Expenditures and Growth Proxy on the Probability of Meeting or Beating Analysts' Revenue Forecasts depending on Business Strategy Proxy (Volatility of R\&D Expenditures)

Model: Prob $(M B R=1 \mid X)=F\left(\alpha_{0}+\alpha_{1} M_{t o_{B}, t}+\alpha_{2}\right.$ Advertising $_{j, t}+\alpha_{3} G_{R O W T H_{j, t}} \times A D V_{j, t}+\alpha_{4} L_{T} G_{R I S K}+\alpha_{5}$ Loss $_{j, t}+\alpha_{6}$ Size $_{j, t}$ $+\alpha_{7}$ COL_Earnings $_{j . t}+\alpha_{8}$ Indpro_value $_{j, t}+\alpha_{9}$ POSREVC $_{j, t}+\alpha_{10}|F E|_{j, t}+\alpha_{11} E_{-}$Sur $_{j, t}+\varepsilon_{j, t}$

\begin{tabular}{|c|c|c|c|c|}
\hline \multirow[b]{2}{*}{ VARIABLES } & \multicolumn{2}{|c|}{ HIGH R\&D Volatility } & \multicolumn{2}{|c|}{ LOW R\&D Volatility } \\
\hline & Coefficient & Marginal Effects & Coefficient & Marginal Effects \\
\hline \multirow{2}{*}{ Constant } & 0.32353 & & -0.39297 & \\
\hline & $(0.410)$ & & $(0.251)$ & \\
\hline \multirow{2}{*}{ M_to_B } & 0.12944 & 0.0278 & -0.01340 & -0.00307 \\
\hline & $(0.159)$ & & $(0.101)$ & \\
\hline \multirow{2}{*}{ Advertising } & $-0.37646^{* *}$ & $-0.0808^{* *}$ & 0.09863 & 0.0226 \\
\hline & $(0.174)$ & & $(0.105)$ & \\
\hline \multicolumn{5}{|c|}{ Interaction b/w Market-to-Book ratio and Advertising: } \\
\hline \multirow{2}{*}{ MtB_ADV } & $0.90262^{* * *}$ & $0.194^{* * *}$ & 0.22921 & 0.0525 \\
\hline & $(0.266)$ & & $(0.169)$ & \\
\hline \multicolumn{5}{|l|}{ Control Variables: } \\
\hline \multirow{2}{*}{ LTG_RISK } & $0.25239^{* *}$ & $0.0542^{* *}$ & $0.35564^{* * *}$ & $0.0814^{* * *}$ \\
\hline & $(0.126)$ & & $(0.082)$ & \\
\hline \multirow{2}{*}{ Loss } & -0.13765 & -0.0296 & -0.11023 & -0.0252 \\
\hline & $(0.160)$ & & $(0.102)$ & \\
\hline \multirow{2}{*}{ Size } & -0.01482 & -0.00318 & 0.04017 & 0.00920 \\
\hline & $(0.040)$ & & $(0.030)$ & \\
\hline \multirow{2}{*}{ Vol_Earnings } & 0.01751 & 0.00376 & 0.01546 & 0.00354 \\
\hline & $(0.016)$ & & $(0.010)$ & \\
\hline \multirow{2}{*}{ Indpro_value } & -0.00079 & -0.000169 & -0.00089 & -0.000204 \\
\hline & $(0.015)$ & & $(0.009)$ & \\
\hline \multirow{2}{*}{ POSREVC } & $0.38286^{* * *}$ & $0.0822^{* * *}$ & $0.52607^{* * *}$ & $0.120^{* * *}$ \\
\hline & $(0.145)$ & & $(0.098)$ & \\
\hline \multirow{2}{*}{$|\mathbf{F E}|$} & $1.07286^{*}$ & $0.230^{*}$ & 0.52822 & 0.121 \\
\hline & $(0.555)$ & & $(0.344)$ & \\
\hline \multirow{2}{*}{ E_Sur } & $-3.64371^{* * *}$ & $-0.782^{* * *}$ & $-1.90200^{* * *}$ & $-0.436^{* * *}$ \\
\hline & $(0.967)$ & & $(0.652)$ & \\
\hline Log Likelihood & -790.58 & & -2011.81 & \\
\hline Wald Chi-square & 66.21 & & 95.55 & \\
\hline$p$-value & $<0.001$ & & $<0.001$ & \\
\hline Pseudo R-squared & 0.040 & & 0.023 & \\
\hline Total Observations & 1,277 & & 3,095 & \\
\hline
\end{tabular}

\# Z-statistics and based on two-way (firm-year) clustered standard errors. Symbolizations ***, **, and * indicate significance levels at $1 \%, 5 \%$, and $10 \%$, respectively. See Appendix for detailed variable definitions. 


\section{CONCLUSION}

This research examines whether the association between firms' growth properties and advertising expenditures is related with the probability of avoiding negative revenue surprises. I hypothesize that unlike earnings benchmark situation, growth firms are more likely to accomplish targeted revenues, the market expectations for revenue, by increasing their advertising activities because the revenue signals of the growth firms are a crucial and a relevant indicator for market participants to make appropriate investment decisions. Consistent with the conjecture, the results obtained from out empirical analysis show that the interaction between firms' advertising expenditure and growth property is positively related to the probability of meeting or beating the expected revenues.

Additionally, this paper investigates whether the effect of the interaction between advertising and growth property on the likelihood of meeting or exceeding the analysts' revenue forecasts varies depending on the companies' business strategy. I assume that the increase in advertising expenses to boost their sales within a short period of time would be more effective for the growth firms with cost leadership strategy than those with differentiation strategy because of the main objective of advertising varies. The results confirm that, as a supportive evidence for my inference, growth firms classified as cost leaders are more likely to achieve zero or positive revenue surprises by using advertising expenditures than growth firms identified as differentiators. Collectively, the findings reported in this paper suggest that managers decide to increase or decrease advertising expenses depending on the firm's growth property and business strategy to generate desirable revenue news.

This study has a few caveats. First, underlying assumption in this study is that firms' marketing areas have certain level of understanding in firms' cost structures and closely discuss with accounting areas each other. Although it may not be always true for all firms, it is a reasonable assumption because all firm's areas need to be involved to effectively manage operating activities. This assumption is also consistent to previous research focusing on real activity management. However, this factor is still considered as a limitation of this study since it could limit the generalizability of findings documented in this study. Second, this study uses the volatility of R\&D expenditures to classify two business strategies: differentiator and cost leadership. Some may argue that it may not be a perfect measure to completely identify each firm's business strategy. Even if the paper tries to reduce this concern by specifically focusing on top and bottom $30 \%$ of observations in the business strategy classification, it could also be another limitation of this study.

\section{ACKNOWLEDGEMENTS}

This work was supported by the Hankuk University of Foreign Studies Research Fund.

\section{AUTHOR BIOGRAPHY}

Dong Hyun Son is an Assistant Professor of Accounting at Hankuk University of Foreign Studies. E-mail: dson@hufs.ac.kr

\section{REFERENCES}

Athanasakou, V. E., Strong, N. C., \& Walker, M. (2009). Earnings management or forecast guidance to meet analyst expectations?, Accounting and Business Research, 39(1), 3-35.

Bagwell, K (2007). The Economic Analysis of Advertising, Handbook of Industrial Organization, 3, 1701-1844.

Bartov, E., Givoly, D., \& Hayn, C. (2002). The rewards to meeting or beating earnings expectations, Journal of Accounting and Economics, 33(2), 173-204.

Brown, L. D. (2001). A temporal analysis of earnings surprises: Profits versus losses, Journal of Accounting Research, $39(2)$, 221-41.

Burgstahler, D. \& Eames, M. (2006). Management of earnings and analysts' forecasts to achieve zero and small positive earnings surprises, Journal of Business Finance \& Accounting, 33, 633-652.

Callen, J., Robb, S., \& Segal, D. (2008). Revenue manipulation and restatements by loss firms, Auditing: A Journal of Practice \& Theory 27(2), 1-29.

Chandra, U., \& Ro, B. T(2008). The role of revenue in firm valuation, Accounting Horizons, 22, 199.

Chapman, J. C., \& Steenburgh, J. T. (2011). An Investigation of earnings management through marketing actions, Management 
Science 57(1), 72-92.

Carvajal M., Coulton J.J \& Jackson A.B. (2015). Earnings benchmark hierarchy. Accounting \& Finance, 57(1), 87-111.

Cohen, D., Mahruwala, R., \& Zach, T. (2010). The use of advertising activities to meet earnings benchmarks: Evidence from Monthly Data, Review of Accounting Studies, 15(4), 808-832.

Dechow, P. M., S. A. Richardson \& A. I. Tuna. (2000). Are benchmark beaters doing anything wrong?, Working paper, Ann Arbor 1001: 48109-41234.

Ertimur, Y., Livnat, J., \& Martikainen, M. (2003). Differential market reactions to revenue and expense surprises, Review of Accounting Studies, 8(2), 185-211.

Hambrick, D. (1985). Efficiency of product R\&D in business units: the role of strategic context, Academy of Management Journal, 28(3), 527-547.

Hanssens, D. M. (2009) Advertising Impact Generalizations in a Marketing Mix Context, Journal of Advertising Research, 49(2), 127-129.

Jegadeesh, N., \& Livnat, J. (2006). Revenue surprises and stock returns, Journal of Accounting and Economics, 41(1-2), 147-71.

Joshi, A., \& Hanssens, M. D. (2010). The direct and indirect effects of advertising spending on firm value, Journal of Marketing, 74(1), 20-33.

Kasznik, R. \& McNichols, M. F. (2002). Does meeting earnings expectations matter? Evidence from analyst forecast revisions and share prices, Journal of Accounting Research. 40, 727-759.

Lodish, M. L., Abraham, M., Kalmenson, S., Livelsberger, J., Lubetkin, B., Richardson, B., \& Ellen, M. (1995). How T.V. Advertising Works: A Meta-Analysis of 389 Real World Split Cable T.V. Advertising Experiments, Journal of Marketing Research, 32(2), 125-139.

Matsumoto, D. A. (2002). Management's incentives to avoid negative earnings surprises, Accounting Review, 77(3), $483-514$.

McAlister, L., Srinivasan, R., Jindal, N., \& Cannella, A. A. (2016). Advertising effectiveness: the moderating effect of firm strategy, Journal of Marketing Research, 53(2), 207-224.

Miles, R, E, \& Snow, C, C. (1978). Organizational strategy, structure and process, New York: McGraw-Hill Book Co.

Miller, D. (1987). Strategy making and structure: analysis and implications to performance, Academy of Management Journal, $30(1), 7-32$.

Payne, J. \& Robb, S. (2001). Earnings management: the effect of ex ante earnings expectations, Journal of Accounting Auditing and Finance 15, 371-392.

Porter, M.E. (1985). Competitive advantage, creating and sustaining superior performance, Free Press: New York, NY, USA.

Rees, L., \& Sivaramakrishnan, K. (2007). The effect of meeting or beating revenue forecasts on the association between quarterly returns and earnings forecast errors, Contemporary Accounting Research, 24(1), 259-90.

Son, D. H. (2016). Revenue surprises: growth vs value firms., Working Paper, Rutgers University.

Stubben, S. (2006). Do firms use discretionary revenues to meet earnings and revenue targets?, Working Paper, Stanford University.

Zhang, Y. (2006). An empirical analysis of revenue manipulation, Working paper, Columbia University. 


\section{APPENDIX A}

\section{Variable Definitions}

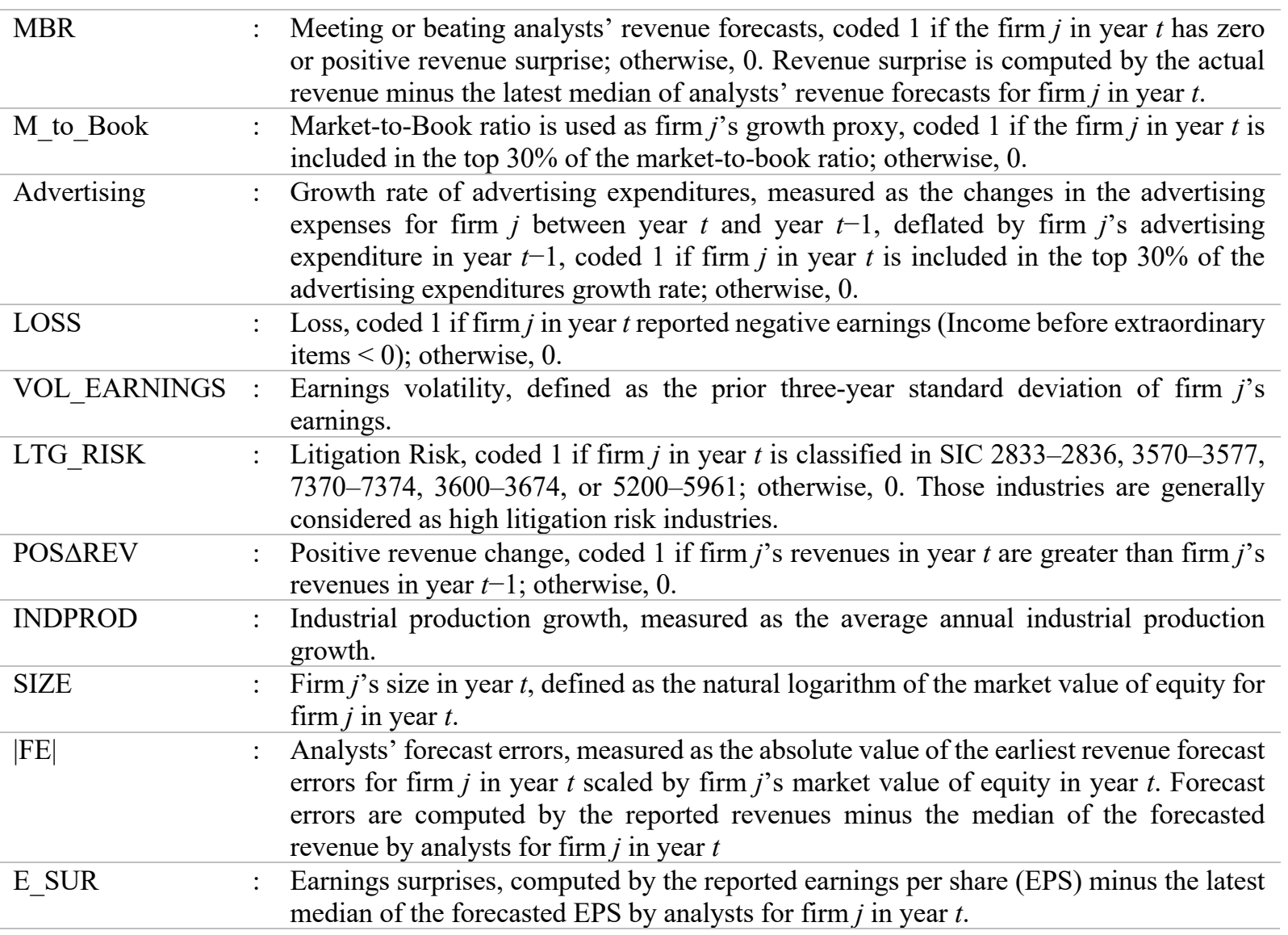




\section{NOTES}

